\title{
Komposisi Jenis Katak (Anura) di Taman Nasional Gunung Palung, Kalimantan Barat
}

\author{
Margie Surahman $^{1}$, Junardi $^{1}$, Tri Rima Setyawati ${ }^{1}$ \\ ${ }^{1}$ Program Studi Biologi, Fakultas MIPA, Universitas Tanjungpura, \\ 1. Prof. Dr. H. Hadari Nawawi, Pontianak, email korespondensi: margiesurahman@ yahoo.co.id
}

\begin{abstract}
The population of frogs in Gunung Palung National Park is indicating a decline due to habitat degradation and hunting. The aim of this research is to determine the species of Anura at five habitat with using Complete Species Inventories (CSI) method combined with Time Search method. The study found 27 Anura species included in 6 families namely Megophryidae (Megophrys nasuta), Bufonidae (Ansonia sp. and A. spinulifer), Microhylidae (Microhyla malang, and M. perparva), Ranidae (Meristogenys jerboa, M. whiteheadi and Staurois guttatus), Dicroglossidae (Limnonectes leporinus and L. kuhlii), and Rhacophoridae (Kurixalus appendiculatus, Rhacophorus sp., R. gauni, and R. pardalis).
\end{abstract}

Kata kunci: Anura, Hutan Kerangas, Gunung Palung, Habitat.

\section{PENDAHULUAN}

Taman Nasonal Gunung Palung (TNGP) merupakan salah satu kawasan konservasi yang terdapat di Kalimantan Barat. Taman Nasional terletak di Kabupaten Kayong Utara dengan luas total $90.000 \mathrm{Ha}$, yang menjadi pusat penelitian flora dan fauna, yaitu Cabang Panti.

Cabang Panti (CP) memiliki luas total $2100 \mathrm{Ha}$ dengan 8 tipe habitat yang berbeda, yaitu habitat hutan rawa gambut, habitat rawa air bening, aluvial, batu berpasir dataran rendah, granit dataran rendah, granit dataran tinggi, pegunungan (Knott, 1999) dan hutan kerangas (Data primer, 2016). Heterogenitas habitat yang tinggi tersebut akan memengaruhi diversitas jenis fauna yang ada di dalamnya, salah satunya adalah Amfibi atau katak (Ordo Anura).

Katak merupakan salah satu komponen ekosistem yang memiliki peran penting sebagai bioindikator lingkungan dan biokontrol populasi, seperti Leptobrachium hassetlii. Populasi katak pada habitat alaminya sering terganggu oleh aktivitas antropogenik salah satunya deforestasi hutan.

Deforestasi hutan yang dilakukan oleh masyarakat tentmnya akan merusak keseimbangan ekosistem dan dapat menurunkan keanekaragaman katak pada kawasan tersebut. Menurut Bawono \& Mashdurohatun (2011), deforestasi hutan akibat penebangan liar dapat menyebabkan penurunan keragaman flora dan fauna pada habitat tersebut. Penebangan liar termasuk ancaman serius bagi keberadaan katak yang akan berdampak pada menurunnya populasi katak akibat rusaknya keseimbangan ekosistem dan hilangnya habitat yang potensial bagi kehidupan katak. Hal ini pernah terjadi di kawasan TNGP pada tahun 2010. Menurut Rifanjani (2015) TNGP telah mengalami penurunan kerapatan hutan sebesar $29,25 \%$.

Ancama lain yang dapat menurunkan populasi katak adalah perburuan. Perburuan yang dilakukan masyarakat di sekitar kawasan umumnya dilakukan untuk memenuhi kebutuhan sehari-hari seperti untuk kosumsi dan perdagangan. Katak memiliki nilai ekonomis bagi beberapa masyarakat lokal yaitu sebagai sumber protein hewani dan sebagai pakan hewan peliharaan. Menurut Kusrini (2008) pengambilan anggota jenis katak dari alam secara langsung untuk konsumsi memberikan sumbangan besar terhadap penurunan populasi katak di alam seperti Limnonectes macrodon. Tujuan dari penelitian ini untuk mengetahui komposisi jenis katak pada setiap tipe habitat di Cabang Panti (CP), Taman Nasional Gunung Palung (TNGP).

\section{BAHAN DAN METODE}

\section{Waktu dan Tempat Penelitian}

Penelitian dilaksanakan pada bulan November hingga Desember 2016, di Kawasan Cabang Panti, Taman Nasional Gunung Palung, Kabupaten Kayong Utara. Identifikasi dan pengolahan data dilaksanakan di Stasiun Penelitian Cabang Panti, Kabupaten Kayong Utara dan Laboratorium Zoologi Fakultas Matematika dan Ilmu Pengetahuan Alam (FMIPA), Universitas Tanjungpura, Pontianak. 


\section{Deskripsi Lokas}

Cabang Panti memiliki sebuah sungai yaitu Sungai Air Putih yang mengalir melewati tujuh habitat mulai dari hutan gunung (hulu) sampai rawa gambut (hilir), kecuali kerangas. Hutan di Cabang Panti termasuk hutan primer karena tidak ditemukan tumbuhan penutup lantai hutan kecuali hutan kerangas.

\section{Alat dan Bahan}

Alat - alat yang digunakan dalam penelitian ini adalah GPS Garmin Etrex, kamera, peta, gunting, tali rafia/pita, jangka sorong Mitutoyo absolute digimatic, plastik packing, sarung tangan lateks, senter, termometer, kertas $\mathrm{pH}$ ( $\mathrm{pH}$ universal), termohigrometer, meteran, bola pimpong, stopwatch, spidol/tipp-ex, botol sampel, karet dan alat tulis. Bahan-bahan yang digunakan dalam penelitian ini adalah alkohol $70 \%$, kapas/tisu dan formalin $4 \%$.

\section{Metode Penelitian}

Penelitian ini dilakukan pada 5 habitat di Cabang Panti, yaitu habitat rawa air tawar (Stasiun I), habitat kerangas (Stasiun II), habitat alluvial (Stasiun III), habitat batu berpasir (Stasiun IV), dan habitat granit dataran rendah (Stasiun V) (Gambar $1)$.

Tabel 1. Lokasi Habitat Stasiun Penelitian

\begin{tabular}{cllc}
\hline Stasiun & \multicolumn{1}{c}{ Habitat } & \multicolumn{1}{c}{ Titik Koordinat } & $\begin{array}{c}\text { Ketinggian } \\
\text { (mdpl) }\end{array}$ \\
\hline I & Rawa Air Tawar (Freshwater Swamp) & $01^{\circ} 12^{\prime} 54,9^{\prime \prime} \mathrm{LS}$ & 53 \\
& & $110^{\circ} 06^{\prime} 12,5^{\prime \prime} \mathrm{BT}$ & \\
II & Kerangas (Kerangas) & $01^{\circ} 13^{\prime} 40,2^{\prime \prime} \mathrm{LS}$ & 44 \\
& & $110^{\circ} 06^{\prime} 07,3^{\prime \prime} \mathrm{BT}$ & \\
III & Alluvial (Alluvial Bench) & $01^{\circ} 13^{\prime} 28,8^{\prime \prime} \mathrm{LS}$ & \\
& & $110^{\circ} 06^{\prime} 12,7^{\prime \prime} \mathrm{BT}$ & 47 \\
IV & Batu Berpasir Dataran Rendah (Low land stone) & $01^{\circ} 13^{\prime} 07,7^{\prime \prime} \mathrm{LS}$ & \\
& & $110^{\circ} 06^{\prime} 16,9^{\prime \prime} \mathrm{BT}$ & 53 \\
V & Granit Dataran Rendah (Lowland Granite) & $01^{\circ} 13^{\prime} 09,8^{\prime \prime} \mathrm{LS}$ & \\
& & $110^{\circ} 06^{\prime} 42,4^{\prime \prime} \mathrm{BT}$ & 107 \\
\hline
\end{tabular}

Keterangan : LS (Lintang Selatan) dan BT (Bujur Timur)

Metode yang digunakan dalam penelitian ini yaitu Complete Species Inventories (CSI) (Heyer et al., 1994) yang dipadukan dengan metode Time Search (Kusrini, 2008). Metode ini dilakukan dengan melakukan pencarian di sekitar perairan dan dibatasi selama 4 jam terhitung mulai pukul 18.00 WIB. Pengulangan dilakukan hingga tidak ada penambahan jenis pada setiap lokasi sampling. Preparasi dilakukan dengan menyuntikkan formalin $4 \%$ pada bagian ventral kemudian tubuhnya ditutupi dengan tisu yang telah dibasahi formalin $4 \%$ selama 48 jam. Sampel dicuci dengan air mengalir dan direndam dalam alkohol $70 \%$. Sampel kemudian diidentifikasi menggunakan buku Inger \& Stuebing (1999) dan Iskandar (1998), dengan memperhatikan karakter dan data morfologi tubuh, seperti Snout Vent Length (SVL), panjang tungai belakang, panjang tungkai depan dan panjang kepala. 


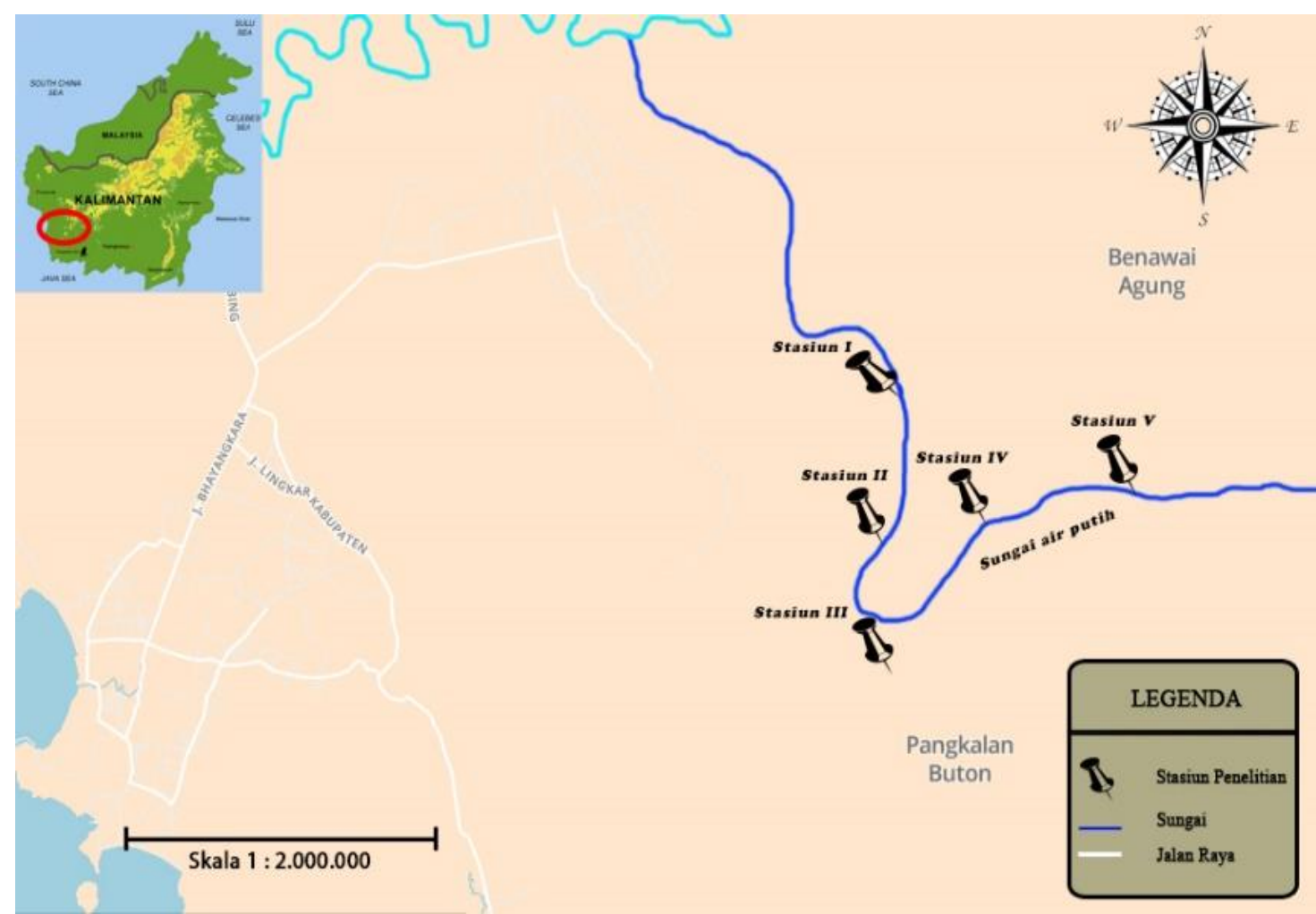

Gambar 1. Peta Stasiun Penelitian di Cabang Panti Taman Nasional Gunung Palung

\section{HASIL}

\section{Komposisi dan Morfometri Jenis}

Jenis-jenis Anura yang ditemukan di Kawasan Cabang Panti, Taman Nasional Gunung Palung yang dilaksanakan selama 15 hari berjumlah 308 individu terdiri atas 27 jenis yang termasuk dalam enam famili, yaitu: Megophryidae (tiga jenis), Bufonidae (enam jenis), Microhylidae (tiga jenis) Ranidae (enam jenis), Dicroglossidae (tiga jenis) dan Rhacophoridae (enam jenis).

Tabel 2. Komposisi Anura Di Stasiun Cabang Panti, Taman Nasional Gunung Palung

\begin{tabular}{|c|c|c|c|c|c|c|}
\hline \multirow{2}{*}{ Jenis } & \multirow{2}{*}{ Status } & \multicolumn{5}{|c|}{ Keberadan Individu } \\
\hline & & S I & S II & S III & S IV & S V \\
\hline \multicolumn{7}{|l|}{ Megophryidae } \\
\hline Leptolalax gracillis & NT & - & - & - & + & + \\
\hline Leptobrachium abbotti & LC & - & - & - & - & + \\
\hline Megophrys nasuta & LC & - & - & - & - & + \\
\hline \multicolumn{7}{|l|}{ Bufonidae } \\
\hline Ansonia sp. & $\mathrm{DD}$ & - & - & - & - & + \\
\hline A. longidigita & NT & - & - & - & + & - \\
\hline A. spinulifer & NT & - & - & - & + & + \\
\hline Ingerophrynus divergens & LC & + & - & + & + & + \\
\hline Phrynoidis asper & LC & + & - & - & - & - \\
\hline Pseudobufo subasper & LC & - & - & + & - & - \\
\hline \multicolumn{7}{|l|}{ Microhylidae } \\
\hline Microhyla berdmorei & LC & + & - & + & - & - \\
\hline M. malang & $\mathrm{DD}$ & - & + & + & - & - \\
\hline M. perparva & NT & + & + & + & - & - \\
\hline
\end{tabular}


Lanjutan Tabel 2. Komposisi Anura Di Stasiun Cabang Panti, Taman Nasional Gunung Palung

\begin{tabular}{|c|c|c|c|c|c|c|}
\hline \multirow{2}{*}{ Jenis } & \multirow{2}{*}{ Status } & \multicolumn{5}{|c|}{ Keberadaan Individu } \\
\hline & & S I & S II & S III & S IV & S V \\
\hline \multicolumn{7}{|l|}{ Ranidae } \\
\hline Chalcorana megalonesa & $\mathrm{LC}$ & + & + & + & + & - \\
\hline Meristogenys jerboa & VU & - & - & + & + & + \\
\hline M. whiteheadi & NT & - & - & - & - & + \\
\hline Pulcharana baramica & $\mathrm{LC}$ & + & + & + & + & - \\
\hline P. signata & LC & + & - & + & - & - \\
\hline Staurois guttatus & $\mathrm{LC}$ & - & - & - & + & + \\
\hline \multicolumn{7}{|l|}{ Dicrogolssidae } \\
\hline Limnonecetes kuhlii & $\mathrm{LC}$ & - & - & - & + & + \\
\hline L. leporinus & LC & + & - & + & + & + \\
\hline L. paramacrodon & NT & - & - & + & - & - \\
\hline \multicolumn{7}{|l|}{ Rhacophoridae } \\
\hline Kurixalus appendiculatus & $\mathrm{LC}$ & + & + & - & - & - \\
\hline Polypedates colletti & LC & - & + & - & + & - \\
\hline P. macrotis & $\mathrm{LC}$ & + & - & + & + & + \\
\hline Rhacophorus sp. & DD & + & - & - & - & - \\
\hline R. gauni & NT & - & - & - & + & - \\
\hline R.pardalis & $\mathrm{LC}$ & - & - & + & - & + \\
\hline
\end{tabular}

Keterangan: (*) Paling Banyak, (**) Paling Sedikit, dan (S) stasiun. Kategori Status Konservasi Menurut IUCN (2008) yaitu Vulnerable (VU), Near Threatened (NT), Least Concern (LC) dan Data Deficient (DD).

Parameter morfometri Anura yang diukur meliputi panjang kepala, Snout Vent Lenght
(SVL), panjang tungkai depan, dan panjang tungkai belakang (Tabel 3).

Tabel 3. Morfometri Anura di Cabang Panti, Gunung Palung

\begin{tabular}{lrrrr}
\hline Jenis & SVL $(\mathbf{m m})$ & $\mathbf{P T B}(\mathbf{m m})$ & PTD $(\mathbf{m m})$ & PK (mm) \\
\hline Asp. & $22.77(\mathrm{SD} \pm 0)$ & $36.46(\mathrm{SD} \pm 0)$ & $17.59(\mathrm{SD} \pm 0)$ & $7.47(\mathrm{SD} \pm 0)$ \\
$\mathrm{Al}$ & $39,92-56,96(\mathrm{SD} \pm 9,77)$ & $66,05-97,34(\mathrm{SD} \pm 17,96)$ & $33,08-51,76(\mathrm{SD} \pm 9,65)$ & $11,87-18,26(\mathrm{SD} \pm 3,35)$ \\
$\mathrm{As}$ & $34,12-40,54(\mathrm{SD} \pm 3,59)$ & $58,03-66,78(\mathrm{SD} \pm 4,75)$ & $30,74-34,75(\mathrm{SD} \pm 2,21)$ & $11,47-12,06(\mathrm{SD} \pm 0,30)$ \\
$\mathrm{Cm}$ & $30,29-50,93(\mathrm{SD} \pm 8,57)$ & $63,10-110,91(\mathrm{SD} \pm 17,48)$ & $24,59-35,00(\mathrm{SD} \pm 4,09)$ & $12,29-18,39(\mathrm{SD} \pm 2,26)$ \\
$\mathrm{Id}$ & $33,00-34,92(\mathrm{SD} \pm 5,36)$ & $52,70-56,00(\mathrm{SD} \pm 7,02)$ & $27,90-29,00(\mathrm{SD} \pm 3,20)$ & $10,69-11,00(\mathrm{SD} \pm 0,68)$ \\
$\mathrm{Ka}$ & $32,86-35,19(\mathrm{SD} \pm 1,15)$ & $48,86-56,56(\mathrm{SD} \pm 2,88)$ & $16,56-23,67(\mathrm{SD} \pm 2,98)$ & $12,49-14,72(\mathrm{SD} \pm 0,89)$ \\
$\mathrm{La}$ & $35.42(\mathrm{SD} \pm 0)$ & $54.95(\mathrm{SD} \pm 0)$ & $21.96(\mathrm{SD} \pm 0)$ & $14.65(\mathrm{SD} \pm 0)$ \\
$\mathrm{Lg}$ & $18,11-35,77(\mathrm{SD} \pm 9,58)$ & $26,46-66.78(\mathrm{SD} \pm 21,41)$ & $10,09-34,75(\mathrm{SD} \pm 13,63)$ & $6,05-12,06(\mathrm{SD} \pm 3,23)$ \\
$\mathrm{Lk}$ & $30,10-52,35(\mathrm{SD} \pm 9,55)$ & $49,87-85,25(\mathrm{SD} \pm 14,54)$ & $21,68-47,72(\mathrm{SD} \pm 9,57)$ & $10,44-23,13(\mathrm{SD} \pm 4,94)$ \\
$\mathrm{Ll}$ & $29,17-144,00(\mathrm{SD} \pm 41,62)$ & $44,68-235,00(\mathrm{SD} \pm 60,24)$ & $17,61-70,00(\mathrm{SD} \pm 21,61)$ & $13,05-62,00(\mathrm{SD} \pm 16,49)$ \\
$\mathrm{Lp}$ & $22,00-33,67(\mathrm{SD} \pm 24,81)$ & $39,00-58,41(\mathrm{SD} \pm 13,67)$ & $12,00-19,96(\mathrm{SD} \pm 15,37)$ & $8,0012,84(\mathrm{SD} \pm 5,87)$ \\
$\mathrm{Mn}$ & $122.13(\mathrm{SD} \pm 0)$ & $118.91(\mathrm{SD} \pm 0)$ & $78.52(\mathrm{SD} \pm 0)$ & $36.12(\mathrm{SD} \pm 0)$ \\
$\mathrm{Mj}$ & $31,00-50,93(\mathrm{SD} \pm 10,33)$ & $63,00-110,91(\mathrm{SD} \pm 23,51)$ & $20,85-35,00(\mathrm{SD} \pm 6,52)$ & $11,00-18,39(\mathrm{SD} \pm 3,42)$ \\
\hline
\end{tabular}


Lanjutan tabel 3. Morfometri Anura di Cabang Panti, Gunung Palung

\begin{tabular}{lrrrr}
\hline Jenis & SVL $(\mathbf{m m})$ & PTB $(\mathbf{m m})$ & PTD $(\mathbf{m m})$ & PK (mm) \\
\hline $\mathrm{Mw}$ & $49,00-50,91(\mathrm{SD} \pm 1,00)$ & $101,88-110,35(\mathrm{SD} \pm 4,44)$ & $33,01-35,96(\mathrm{SD} \pm 1,48)$ & $10,98-19,75(\mathrm{SD} \pm 4,82)$ \\
$\mathrm{Mb}$ & $23,91-30,14(\mathrm{SD} \pm 4,41)$ & $49,19-62,47(\mathrm{SD} \pm 9,39)$ & $12,05-15,08(\mathrm{SD} \pm 2,14)$ & $8,16-9,14(\mathrm{SD} \pm 0,69)$ \\
$\mathrm{Mm}$ & $16,83-23,28(\mathrm{SD} \pm 3,68)$ & $37,00-47,80(\mathrm{SD} \pm 5,40)$ & $11,25-13,87(\mathrm{SD} \pm 1,32)$ & $5,24-6,87(\mathrm{SD} \pm 0,83)$ \\
$\mathrm{Mp}$ & $11,36-13,19(\mathrm{SD} \pm 0,76)$ & $24,29-26,42(\mathrm{SD} \pm 1,15)$ & $7,79-8,72(\mathrm{SD} \pm 0,41)$ & $2,78-4,14(\mathrm{SD} \pm 0,59)$ \\
$\mathrm{Pa}$ & $38.83(\mathrm{SD} \pm 0)$ & $57.59(\mathrm{SD} \pm 0)$ & $26.24(\mathrm{SD} \pm 0)$ & $14.61(\mathrm{SD} \pm 0)$ \\
$\mathrm{Pc}$ & $44,38-59,17(\mathrm{SD} \pm 6,98)$ & $79,43-113,01(\mathrm{SD} \pm 14,34)$ & $31,95-37,87(\mathrm{SD} \pm 3,37)$ & $16,39-20.08(\mathrm{SD} \pm 1,65)$ \\
$\mathrm{Pm}$ & $52,39-78,74(\mathrm{SD} \pm 18,63)$ & $86,96-126,20(\mathrm{SD} \pm 27,75)$ & $41,98-55,45(\mathrm{SD} \pm 9,52)$ & $18,95-26,67(\mathrm{SD} \pm 5,46)$ \\
$\mathrm{Ps}$ & $70.00(\mathrm{SD} \pm 0)$ & $68.00(\mathrm{SD} \pm 0)$ & $42.00(\mathrm{SD} \pm 0)$ & $20.00(\mathrm{SD} \pm 0)$ \\
$\mathrm{Pb}$ & $25,34-63,57(\mathrm{SD} \pm 16,69)$ & $39,65-103,84(\mathrm{SD} \pm 29,07)$ & $17,24-51,76(\mathrm{SD} \pm 14,89)$ & $8,07-18,29(\mathrm{SD} \pm 5,23)$ \\
$\mathrm{Psi}$ & $38,28-39,47(\mathrm{SD} \pm 0,60)$ & $63,92-69,64(\mathrm{SD} \pm 3,17)$ & $26,64-28,73(\mathrm{SD} \pm 1,07)$ & $12,05-13,83(\mathrm{SD} \pm 0,90)$ \\
$\mathrm{Rsp}$. & $30.26(\mathrm{SD} \pm 0)$ & $50.56(\mathrm{SD} \pm 0)$ & $19.62(\mathrm{SD} \pm 0)$ & $10.31(\mathrm{SD} \pm 0)$ \\
$\mathrm{Rg}$ & $37.08(\mathrm{SD} \pm 0)$ & $65.15(\mathrm{SD} \pm 0)$ & $25.48(\mathrm{SD} \pm 0)$ & $10.42(\mathrm{SD} \pm 0)$ \\
$\mathrm{Rp}$ & $46,65-64,42(\mathrm{SD} \pm 36,89)$ & $79,89-113,08(\mathrm{SD} \pm 30,97)$ & $30,29-43,05(\mathrm{SD} \pm 23,85)$ & $14,95-21,47(\mathrm{SD} \pm 9,95)$ \\
$\mathrm{Sg}$ & $33,95-47,62(\mathrm{SD} \pm 7,66)$ & $63,39-87,25(\mathrm{SD} \pm 12,80)$ & $21,96-34,12(\mathrm{SD} \pm 6,12)$ & $14,22-19,67(\mathrm{SD} \pm 2,72)$ \\
\hline
\end{tabular}

Keterangan: SVL (Snout Vent Lenght), PTB (Panjang Tungai Belakang), PTD (Panjang Tungkai Depan), dan PK (Panjang Kepala), SD (Standar Devisiasi), Asp (Ansonia sp.), Al (Ansonia longidigita), AS (Ansonia spinulifer),

$\mathrm{Cm}$ (Chalchorana megalonesa), Id (Ingerophrynus divergens), Ka (Kurixalus appendiculatus), La (Leptobranchium abbotti), Lg (Leptolalax gracillis), Lk (Limnonectes kuhlii), Ll(Limnonectes leporinus), Lp (Limnonectes paramacrodon), Mn (Megophrys nasuta), $\mathrm{Mj}$ (Meristogenys jerboa), Mw (Meristogenys whiteheadi), $\mathrm{Mb}$ (Microhyla berdmorei), $\mathrm{Mm}$ (Microhyla malang), $\mathrm{Mp}$ (Microhyla perparva), Pa (Phrynoidis asper), Pc (Polypedates colletti), Pm (Polypedates macrotis), Ps (Pseudobufo subasper), $\mathrm{Pb}$ (Pulcharana baramica), Psi (Pulcharana signata), Rsp (Rhacophorus sp.), Rg (Rhacophorus gauni), Rp (Rhacophorus pardalis), dan Sg (Staurois guttatus).

\section{Deskripsi Jenis}

\section{Family: Megophryidae}

\section{Leptolalax gracillis}

Leptolalax gracilis memiliki panjang tubuh (SVL) 18,11-35,77mm. Leptolalax gracilis memiliki kepala yang hampir sama lebarnya dengan bagian badannya. Bagian atas kepala antara mata terdapat corak coklat tua berbentuk huruf "V" yang tebal dan menghubungkan kedua mata. Anterior mata terdapat corak hitam berbentuk bulat yang terletak antara mata dan lubang hidung. Tubuh $L$. gracillis berukuran kecil dan kurus, berwarna coklat muda dengan corak berbentuk bulat berwarna coklat tua pada bagian dorsal.

Bagian siku pada tungkai depan memiliki warna yang cerah dan jelas yang sangat berbeda dari bagian branchium dan antebranchium. Menurut Inger \& Stuebing (2002), L. gracillis memiliki ciri khas yang dapat dibedakan dengan jenis Leptolalax lainnya, yaitu adanya warna putih susu pada bagian sikut atau warna yang jelas berbeda dari warna lengan atas dan bawah tungkai depan

\section{Leptobrachium abbotti}

Leptobrachium abbotti memiliki panjang tubuh (SVL) 35,42mm. Leptobrachium abbotti memiliki kepala yang lebih lebar dari panjang, dengan moncong yang hampir membulat. Lebar kepala lebih lebar dibandingkan dengan lebar badan, sehingga tubuhnya tampak mengerucut kebagian posterior tubuh. Mata L. abbotti berwarna hitam polos dengan bagian sudut mata (sclera) berwarna putih.

Tungkai depan L. abbotti panjang dan kurus terutama pada bagian antebranchium. Kulit pada tungkai depan sedikit mengkerut dan terlipat membujur. Leptobrachium abbotti memiliki tubuh berwarna hitam sedikit keabu-abuan pada bagian dorsal dan lateral tubuhnya, kulit sedikit mengkerut. Bagian ventral berwarna abu-abu dengan bercak putih sedangkan bagian bawah kepala berwarna putih keabu-abuan dengan bercak kehitaman.

Menurut Abdiansyah (2011) L. abbotti memiliki kepala yang lebar dan mata yang menonjol. Kaki berukuran pendek dan ramping. Warna dorsal 
coklat hingga hitam sedangkan ventral ditandai dengan warna putih tebal dan bintik-bintik gelap.

\section{Megophrys nasuta}

Megophrys nasuta memiliki panjang tubuh (SVL) $122,13 \mathrm{~mm}$. Megophrys nasuta memiliki ciri khas pada bagian kepalanya yaitu terdapat tonjolan berbentuk segitiga pada bagian atas kelopak mata dan ujung moncong. Tonjolan kulit tersebut merupakan terusan dari kelopak mata dan kulit pada ujung moncong atas. Celah mulut lebar, hingga mencapai dekat pangkal tungkai depan dengan sudut celah mulut terdapat tonjolan kulit seperti duri yang sangat jelas. Das et al., (2007) menemukan $M$. nasuta dengan panjang tubuh lebih dari $125 \mathrm{~mm}$, dengan karakteristik khas dari jenis ini adalah adanya tonjolan kulit pada bagian kelopak mata atas yang mengarah ke moncong.

Bagian dorsal tubuh berwarna coklat muda dengan corak coklat tua, terdapat lima tonjolan pada bagian dorsal berbentuk kerucut, berwarna hitam, kecil dan keras. Bagian lateral tubuh berwana coklat tua gelap began corak hitam dan sedikit keunguan. Megophrys nasuta memiliki sederet tonjolan kulit kecil dan pendek pada sisi lateral tubuh hingga dekat pangkat femur dan berwarna putih. Menurut Das et al., (2007) jenis ini memiliki warna coklat pada tubuh bagian dorsal dengan subocular berwarna hitam.

\section{Family: Bufonidae}

\section{Ansonia sp.}

Ansonia sp. memiliki panjang tubuh (SVL) $22,77 \mathrm{~mm}$. Jenis ini memiliki moncong yang pendek, meruncing dengan ujung yang sedikit rata. Bagian sudut posterior mata berwarna hijau muda kekuningan. Permukaan kulit kasar, dan terdapat tonjolan kulit seperti bentol-bentol berukuran kecil dan merata dari bagian dorsal kepala hingga badan.

Sisi tubuh terdapat bulatan-bulatan kecil hingga besar berwarna hijau muda kekuningan. Permukaan ventral berbentol-bentol kecil dengan tinggi yang sama. Ventral berwarna hitam dengan bintik-bintik hijau muda kekuningan berukuran besar pada bagian sisi ventral dan bintik-bintik berukuran lebih kecil pada bagian tengan ventral. Bagian bawah kepala berwarna hitam polos. Tungkai berwarna hitam dengan garis hijau muda melintang pada bagian dorsal tungkai. Permukaan kulit tungkai tertutupi tonjolan kulit berbentuk kerucut, kecil, pendek dan tidak rapat.
Menurut Malkmus et al., (2002) jenis Ansonia dari Borneo memiliki ukuran tubuh yang kecil hingga sedang, berwarna coklat hingga hitam dengan ukuran tubuh $<65 \mathrm{~mm}$. Tubuh sedikit pipih dorsolateral, memanjang dan ramping serta berkaki panjang. Sebagian besar memiliki moncong yang lebih panjang dari mulut jika dilihat dari samping. Ujung jari tungkai depan dan belakang tumpul, dengan tungkai depan berselaput hanya di dasar jari. Kulit kasar, biasanya tertutupi oleh kutil-kutil dan tidak memiliki kelenjar paratoid.

\section{Ansonia longidigita}

Ansonia longidigita memiliki panjang tubuh (SVL) 39,92-56,96mm. Ansonia longidigita memiliki dorsal berwarna coklat terang hingga coklat tua, permukaan kulit kasar tertutup oleh tonjolan kulit seperti bentol yang jelas terlihat. Sisi tubuh terdapat bercak-bercak merah dengan permukaan kulit berbentol (tidak rapat). Ventral berwarna putih dengan bercak-bercak berwarna kuning. Tungkai depan dan belakang memiliki permukaan kulit yang kasar tertutupi tonjolan kulit seperti bentol yang meruncing dan berukuran panjang. Tungkai depan terdapat bercak merah yang jelas tampak membentang di sepanjang bagian branchium. Tungkai belakang kurus dan panjang berwarna coklat dengan garis melintang pada bagian dorsal.

Menurut Das et al., (2007) A. longidigita memiliki panjang tubuh hingga $65 \mathrm{~mm}$, bertubuh ramping. Tubuh bagian atas berwarna coklat hingga coklat kehitaman, dengan beberapa bintik terang. Tungkai belakang bagian atas terdapat garis coklat gelap melintang.

\section{Ansonia spinulifer}

Ansonia spinulifer memiliki panjang tubuh (SVL) $34,12-40,54 \mathrm{~mm}$. Tubuh bagian dorsal berwarna hitam hingga hitam keabu-abuan dengan corak berwarna merah cerah dekat tengkuk kepala antar bahu. Bagian dorsal tertutupi oleh tonjolan kulit berbentuk seperti duri yang rapat dengan ujung berwarna lebih hitam.

Bagian lateral tubuh berwarna hitam kaabu-abuan dengan corak merah. Bagian ventral tubuh berbentol-bentol kecil berwarna hitam yang di antaranya terdapat bentol-bentol berwarna putih seperti mutiara. Permukaan ventral terasa halus ketika diraba. Tungkai berwarna hitam dengan garis merah melintang. Permukaan kulit pada tungkai 
tertutupi tonjolan kulit yang berbentuk seperti kerucut berukuran kecil.

Menurut Haas et al., (2018) A. spinulifer memiliki moncong yang tumpul, bertubuh ramping, dorsal berwarna hitam, dengan kutil berwarna kekuningan atau kemerahan cerah pada bagian lateral, dan pada tungkai belakang dan depan terdapat kutil berwarna cerah yang melintang. corak berwarna krem, abuabu atau kemerahan di antara kedua bahu. Dorsal kasar tertutup kutil berbentuk duri, dan bagian perut terdapat tonjoan-tonjolan kulit seperti pasir berwarna berwarna coklat gelap atau hitam dan corak putih.

\section{Ingerophrynus divergens}

Ingerophrynus divergens memiliki panjang tubuh (SVL) berkisar antara 33,00-34,92mm. Kepala bagian superior di antara mata terdapat sepasang lipatan kulit memanjang. Menurut Malkmus et al. (2002), sepasang lipatan kulit yang berada di antara mata memiliki struktur yang keras seperti terjadi penulangan dan lipatan ini merupakan salah satu karakteristik yang dimiliki I. divergens. Posterior mata terdapat kelenjar paratoid berbentuk lonjong dan tonjolan-tonjolan kulit yang berbaris terputusputus hingga pangkal femur .

Bagian dorsal dan lateral tubuh berwarna coklat muda hingga coklat tua, dan ada beberapa tonjolan kulit berwarna hitam. Bagian ventral tubuh berbentol-bentol kecil, rapat, dan berwarna coklat muda terang dengan beberapa bercak keabu-abuan. Bagian bawah kepala berwarna lebih gelap dari ventral. Menurut Kamsi (2017) I. divergent memiliki tekstur kulit yang kasar tertutup oleh bintil-bintil, berwarna coklat dan memiliki ukuran tubuh berkisar antara $28-43 \mathrm{~mm}$ pada jantan dan 36$55 \mathrm{~mm}$ pada betina.

\section{Phrynoidis asper}

Phrynoidis asper memiliki panjang tubuh (SVL) $38,83 \mathrm{~mm}$. Permukaan kulit kepala bagian dorsal tertutupi oleh tonjolan kulit seperti duri berbentuk kerucut yang kecil dan pendek. Tympanum tidak jelas terlihat tertutupi kulit yang berduri. Kelenjar paratoid terletak pada bagian posterior mata, berukuran kecil dan tersamarkan duri. Tubuh bagian dorsal dan lateral memiliki warna coklat tua keabuabuan dan kulit yang tertutupi oleh tonjolan kulit. Tojolan kulit tersebut seperti duri berbentuk kerucut dengan ukuran dan tinggi yang beragam. Ujungujung duri berwarna hitam. Bagian ventral tubuh berwarna abu-abu keputihan yang semakin kearah kloaka semakin berwarna putih.

Menurut Abdiansyah (2011) P. asper memiliki ukuran tubuh berkisar antara 70-120mm, permukaan kulit sangat kasar tertutupi oleh tonjolan-tonjolan kulit. Kelenjar paratoid berbentuk lonjong dan selaput renang sanpai ke ujung jari. Warna tubuh kehitam-hitaman hingga coklat tua.

\section{Pseudobufo subasper}

Pseudobufo subasper memiliki panjang tubuh (SVL) 70,00mm. Pseudobufo subasper memiliki moncong yang pendek dan runcing. Ujung moncong $P$. subasper sedikit menghadap ke arah atas dan dan lubang hidung berada di dorso-anterior kepala dan terproyeksi ke arah atas. Permukaan kulit kepala berbentol-bentol besar namun tidak tinggi.

Tubuh bagian dorsal berwarna coklat tua keabuabuan dengan permukaan kulit yang kasar tertutupi betol-bentol berukuran besar. Sebuah garis samarsamar berwarna putih kekuningan memanjang dari ujung moncong hingga kloaka. Permukaan kulit pada bagian lateral tubuh sama dengan bagian dorsal, tapi pada lateral tubuh terdapat dua warna kulit yaitu coklat terang pada bagian dekat dorsolateral dan warna hitam pada bagian dekat ventral.

Tungkai depan memiliki ukuran yang pendek dan sedikit besar jika dibandingkan dengan jenis Bufonidae lainnya. Jari pada tungkai depan tampak besar dengan ujung yang tumpul dan tidak berselaput. Tungkai belakang berukuran besar terutama pada bagian femur. Jari-jari besar dan panjang dengan ujung yang tumpul. Jari-jari tungkai belakang berselaput hingga ke ujung jari dan tebal.

Menurut Inger et al., (2005) P. subasper memiliki tubuh yang besar dan gemuk serta berkepala kecil. Lubang hidung terapat di bagian dorsal moncong. Ujung jari-jari tungkai depan membulat, dan sedikit berselaput sedangkan jari pada tungkai belakang berselaput penuh. Kulit belakang kasar tertutupi oleh kuti-kutil bulat besar. Kulit dorsal dan sisi berwarna coklat dengan garis kuning atau oranye kekuningan.

\section{Family: Microhylidae}

\section{Microhyla berdmorei}


Microhyla berdmorei merupakan salah satu jenis katak bermulut sempit dengan panjang tubuh (SVL) berkisar antara 23,91-30,14mm. Bagian atas kepala berwarna coklat muda dan bagian bawah kepala berwarna putih keabu-abuan. Microhya berdmorei memiliki tubuh yang gemuk hampir bulat, dengan bagian dorsal badan berwarna coklat muda. Microhyla berdmorei memiliki corak berwarna coklat tua berbentuk seperti mata panah yang semakin melebar ke arah posterior tubuh hingga pangkal femur. Bagian ventral tubuh berwarna kuning cerah.

Menurut Stuart (2006) M. berdmorei memiliki panjang tubuh berkisar antara $30,5-41,7 \mathrm{~mm}$. Ujung moncong tumpul, bagian bawah kepala gelap. Menurut Haas et al., (2018) M. berdmorei memiliki tubuh yang lebar dengan tungkai belakang yang panjang, ujung jari tungkai belakang jelas melebar membentuk keping. Jari tungkai belakang berselaput penuh kecuali jari ke empat. Dorsal berwarna coklat dengan corak polygonal berwarna gelap dan tepian cerah dari pundak hingga tengah dorsal, sedangkaan vental berwarna kuning.

\section{Microhyla malang}

Microhyla malang memiliki panjang tubuh (SVL) berkisar antara $16,83-23,38 \mathrm{~mm}$. Ujung moncong tumpul, warna dorsal dan lateral kepala coklat muda sedangkan bawah kepala berwarna putih bercakbercak abu-abu gelap. Bibir bagian atas mulut terdapat beberapa bintik-bintik hitam yang jelas. Tubuh bagian dorsal dan lateral $M$. malang berwarna coklat muda dengan bagian dorsal terdapat corak menyerupai dua mata panah yang tersusun berbaris ke belakang dan corak tersebut berwarna coklat tua dengan bagian tepi berwarna lebih cerah. Bagian lateral tubuh terdapat bercak hitam yang jelas di sepanjang pangkal tungkai depan hingga pertengahan antara tungkai depan dan belakang. Ventral tubuh berwarna putih polos.

Menurut Matsui (2011) M. malang merupakan katak berukuran medium dengan panjang tubuh berkisar antara $18-22 \mathrm{~mm}$, moncong tumpul dan tampak membulat. Corak pada bagian dorsal berwarna gelap dengan garis luar berwarna putih. Garis krem dibawah lipatan supratimpanik yang tidak dibatasi warna gelap. Bagian lateral tubuh terdapat corak gelap tidak beraturan mulai dari bagian atas tungkai depan hingga bagian tengah tubuh.

\section{Microhyla perparva}

Microhyla perparva memiliki panjang tubuh (SVL) berkisar antara 11,36-13,19mm. Tubuh berukuran kecil dan gemuk, dengan warna dorsal coklat muda dan terdapat corak mata panah yang membulat dan melebar kebagian posterior tubuh berwarna coklat tua. Permukaan kulit halus dan licin tanpa bintilbintil. Kulit bagian ventral tubuh berwarna putih dan mengerucut kearah bawah kepala.

Tungkai depan memiliki ukuran yang kecil dan pendek. Jari-jari pada tungkai depan hanya memiliki tiga jari. Tungkai belakang memiliki ukuran lebih dari dua kali panjang tubuhnya dengan bagian femur yang lebih besar dan berotot. Tungkai belakang berwarna coklat terangan dengan garis melintang berwarna coklat tua dan tepi garis berwarna cerah.

Menurut Inger et al., (2005) M. perparva merupakan katak berukuran kecil dengan panjang tubuh hanya $10-15 \mathrm{~mm}$, tetapi memiliki kaki yang panjang. Microhyla perparva merupakan satu dari dua jenis yang memiliki jari pada tungkai depan hanya dua di Borneo. Jari pada tungkai belakang berselaput penuh kecuali jari ke empat. Permukaan kulit licin dengan warna coklat pada bagian dorsal dan berwarna putih pada bagian ventral.

\section{Family: Ranidae}

\section{Chalcorana megalonesa}

Chalcorana megalonesa memiliki pajang tubuh (SVL) berkisar antara 30,29-50,93mm. Chalcorana megalonesa memiliki moncong yang runcing dan panjang. Bibir berwarna perak kekuningan. Tubuh dorsal berwarna coklat dengan sedikit bintik-bintik coklat gelap dan lateral tubuh berwarna hijau begitu juga dengan sisi bagian kepala. Ventral tubuh berwarna putih polos. Tungkai depan memiliki jari yang kurus dan panjang dengan ujung yang melebar berbentuk belah ketupat dan berukuraan besar serta tidak berselaput. Tungkai belakang berukuran kecil dan panjang dengan jari yang berselaput penuh kecuali jari keempat terdapat satu ruas yang tidak berselaput. Ujung jari pada tungkai belakang sedikit melebar dengan ukuran lebih kecil dari tungkai depan.

Menurut Inger et al., (2009) C. megalonesa memiliki bentuk kepala segitiga, dengan moncong sedikit lebih panjang. Lipatan dorsolateral sempit, permukaan kulit dorsal bergranular, lebih jelasnya pada jantan. Bagian dorsal tungkai belakang 
terdapat garis-garis tebal gelap. Menurut Haas et al., (2018) C. megalonesa memiliki tubuh yang ramping, Jari pada setiap tungkai memiliki ukuran yang panjang, bagian ujung jari jelas melebar membentuk keping dengan circummarginal dan berukuran besar (pada jantan). Bagian dorsal berwarna coklat dengan bintik gelap tidak beraturan. Bibir atas berwarna krem.

\section{Meristogenys jerboa}

Meristogenys jerboa memiliki panjang tubuh (SVL) berkisar antara $31,00-50,93 \mathrm{~mm}$. Jenis ini memiliki tubuh berukuran relatif kecil dan ramping dengan moncong yang runcing dan sempit. Jarak antara lubang hidung dan mata dihubungkan oleh garis hitam. Mata memiliki dua warna yang berbeda, pada bagian atas mata berwarna kuning keemasan dan pada bagian bawah berwarna merah tua kecoklatan dengan ukuran lebih dari setengah mata.

Seluruh permukaan tubuh dorsal berwarna coklat tua, dan halus tanpa tonjolan kulit. Lateral tubuh berwarna hitam (pada habiatnya), mulai dari posterior mata dan mengecil hingga pangkal femur. Warna hitam tersebut berbatasan dengan warna kuning keputihan yang semakin ke arah ventral semakin kuning. Ventral berwarna kuning dengan bagian bawah kepala hingga dada terdapat bercakbercak hitam yang cukup banyak. Bagian bawah kepala, pada kedua sisi posterior kepala dekat pangkal tungkai depan terdapat kantung suara berwarna abu-abu.

Tungkai belakang kurus dan memiliki panjang lebih dari atau sama dengan dua kali panjang tubuhnya (SVL). Tungkai belakang bagian dorsal berwarna coklat tua dengan belang kekuningan. Bagian ventral femur berwarna kuning kemerahan dengan bercak-bercak kuning dekat pangkal femur. Ujungujung jari tungkai belakang mengalami pelebaran berbentuk belah ketupat. Jari-jari berselaput penuh hingga pangkal bantalan jari.

Menurut Das et al., (2007) M. jerboa memiliki panjang tubuh hingga $80 \mathrm{~mm}$, bertubuh ramping dengan tympanum setegah atau kurang dari diameter mata. Jari pada tungkai belakang berselaput penuh. Punggung coklat muda dengan tungkai belakang bagian dorsal bergaris gelap melintang. Bagian ventral dari tibia tidak berwarna atau dengan sedikit pigmen gelap yang tersebar.

\section{Meristogenys whiteheadi}

Meristogenys whiteheadi panjang tubuh (SVL) berkisar antara 49,00-50,91mm. Meristogenys whiteheadi memiliki kepala dengan moncong yang runcing dan panjang. Tympanum jelas terlihat, berwarna merah muda sedikit transparan dan bagian tepi berwarna hitam. Bibir berwarna kuning kehijauan cerah dan pada bibir bawah terdapat belang hitam samar-samar. Bagian atas bibir berwarna kemerahan. Mata memiliki dua warna, pada bagian atas berwarna hijau kekuningan cerah, bagian bawah berwarna hijau kekuningan dengan bercak-bercak merah kecoklatan dan pada bagian daerah sudut mata hingga ke pupil berwarna merah kecoklatan.

Meristogenys whiteheadi warna dorsal hijau tua sedikit gelap dan memiliki lipatan dorsolateral. Lateral tubuh berwarna hijau kekuningan dan terdapat corak bulatan-bulatan hitam yang jelas. Ventral tubuh berwarna putih keemasan mengkilap. Kantung suara terletak pada bagian sudut posterior bawah kepala berwana abu-abu gelap dan sepasang garis kehitaman di antaranya. Bagian dada terdapat sepasang garis atau bercak abu-abu gelap.

Tungkai belakang berukuran kecil dan memiliki panjang minimal dua kali panjang tubuhnya. Dorsal tungkai belakang berwarna coklat muda kehijauan dengan belang-belang coklat tua. Tibia bagian dalam berwarna kemerahan. Ventral Tungkai belakang berwarna kemerah-merahan dan terdapat sedikit bercak kekuningan dekat pangkal femur. Tungkai belakang memiliki selaput yang penuh hingga pangkal pelebaran ujung jari.

Menurut Shimada et al., (2011) M. whiteheadi memiliki dorsal berwarna coklat terang hingga coklat gelap kehijauan, bagian lores terdapat garis gelap hingga bagian canthus. Meristogenys whiteheadi memiliki garis hitam mulai dari belakang mata hingga bagian atas tympanum dan terus memanjang hingga dekat area inguinal. Bagian ventral terdapat garis gelap dekat tungkai depan.

\section{Pulcharana baramica}

Pulcharana baramica memiliki panjang tubuh (SVL) berkisar antara 25,34-63,57mm. Bibir berwarna hitam belang kuning. Tympanum jelas terlihat berwarna coklat tua dengan bagian tengah berwarna lebih cerah. Pulcharana baramica memiliki tubuh dorsal berwarna hitam atau abu-abu gelap dengan corak kuning keputihan yang tidak jelas bentuknya. Permukaan kulit tertutup oleh 
tonjolan kulit yang kecil dan halus. Bagian lateral tubuh berwarna abu-abu gelap kekuningan dengan tonjolan kulit yang sedikit lebih besar dan halus. Bagian ventral tubuh berwarna putih kekuningan dengan corak hitam berukuran besar.

Permukaan kulit pada kedua tungkai terdapat tonjolan kulit yang kecil dan tinggi yang sama. Ujung jari pada kedua tungkai memiliki sedikit pelebaran berbentuk skop. Jari pada tungkai depan tidak memiliki selaput. Jari pada tungkai belakang berselaput dengan formula berikut I 1-1,5 II 1-2 III 1-2,5 IV 2,5-1 V.

Menurut Kamsi et al., (2017) P. baramica memiliki ukuran tubuh berkisar antara 40-65 mm. kulit bertekstur kasar degan permukaan kulit yang tertutupi kelenjar atau bintil-bintil relatif besar dan rata. Ujung jari mengalami sedikit pelebaran berukuran relatif kecil. Sepertiga jari kaki berselaput dan tiga ruas jari kaki keempat tidak berselaput.

\section{Pulcharana signata}

Pulcharana signata memiliki panjang tubuh (SVL) 38,28-39,47mm. Pulcharana signata memiliki tubuh yang kecil dan ramping dengan moncong yang runcing. Permukaan kulit tampak kasar dengan bintil-bintil yang sangat kecil dan licin ketika disentuh. Tubuh berwarna hitam dengan corak oranye pada dorsal yang pada bagian dorsolateralnya dibatasi garis oranye. Bagian ventral tubuh berwarna abu-abu kehitaman bercak putih dan pada bagian bawah kepala berwarna lebih gelap dari bagian ventral.

Tungkai depan memiliki jari yang kurus dengan ujung yang sedikit melebar berbentuk seperti sudip. Jari-jari pada tungkai depan tidak memiliki selaput. Tungkai belakang memiliki ukuran yang lebih panjang dan sedikit lebih besar. Ujung-ujung jari kaki sedikit melebar, dan terdapat selaput di antara jari-jari tungkai belakang.

Menurut Haas et al., (2018) P. signata memiliki tubuh ramping dan berukuran sedang dengan kepala relatif sempit dan moncong cukup panjang. Tungkai belakang cukup panjang dengan ujung jari sedikit membesar. Jari tungkai belakang berselaput setengah. Bagian dorsal tubuh memiliki tekstur bergranular, berwarna hitam dengan bintik berwarna kuning hingga merah. Pulcharana signata memiliki garis mulai dari moncong hingga mata, melewati bagian atas mata dan terus memanjang hingga bagian pangkal femur.

\section{Staurois guttatus}

Staurois guttatus memiliki panjang tubuh (SVL) berkisar antara 33,95-47,62 mm. Tubuh memiliki kulit sedikit kasar karena terdapat tonjolan kulit berukuran kecil pada bagian dorsal dan lateral tubuh. Dorsal umumnya berwarna hijau dengan corak bulatan-bulatan hitam, namun ditemukan juga individu yang memiliki warna hijau kecoklatan dengan corak hitam tidak beraturan. Lateral tubuh berwarna hijau dengan bentol-bentol berukuran kecil, sedangkan bagian ventral berwarna putih kehijauan dan semakin hijau muda ke arah bawah kepala.

Tungkai belakang memiliki ukuran yang panjang dan kecil. Bagian lipatan femur berwarna kebiruan hingga ke bagian posterior ventral. Jari-jari tungkai belakang berukuran kecil dengan ujung jari yang membesar serta pipih dan berukuran lebih kecil dari tungkai depan. Tungkai belakang memiliki selaput di antara jari pertama hingga ke empat bagian dalam berwarna biru muda sedikit bercak hitam. Selaput renang pada tungkai belakang penuh hingga pangkal pelebaran jari.

Menurut Warguez et al., (2013) S. guttatus memiliki rata-rata ukuran tubuh SVL $33 \mathrm{~mm}$. Tubuh relatif ramping dan tungkai tungkai yang ramping dan panjang. Permukaan kulit dorsal bergranular. Ujung jari pada setiap tungkai mengalami pelebaran (circum marginal), jari tungkai belakang berselaput penuh hingga ke ujung jari.

\section{Family: Dicroglossidae}

\section{Limnonectes kuhlii}

Limnonectes kuhlii memiliki panjang tubuh (SVL) $30,10-52,35 \mathrm{~mm}$. Tubuh berwarna coklat dengan corak gelap dengan perawakan yang berotot. Kulit pada seluruh tubuh bagian dorsal berkeriput dan pada bagian lateral tubuh kulit berkerut seperti bintang dan lebih menonjol dari bagian dorsal tubuh. Individu ditemukan memiliki garis yang membujur dari moncong hingga kloaka. Limnonectes kuhlii memiliki moncong yang tumpul dan mata yang terproyeksi hampir ke arah superior kepala. Limnonectes kuhlii garis melintang yang menghubungkan kedua mata berwarna coklat muda. Mata memiliki pupil berbentuk belah ketupat 
dengan bagian tepi berwarna keemasan. Sudutsudut pupil berwarna lebih gelap yang memanjang dan melebar ke daerah iris. Bagian kelopak mata atas terdapat tonjolan kulit seperti kutil berukuran kecil dan jarang.

Menurut Tran et al., (2010) L. kuhlii memiliki panjang tubuh hingga $55,1 \mathrm{~mm}$. Ukuran kepala lebih lebar dibandingkan dengan panjang kepala. Bagian kelopak mata atas terdapat bintil berukuran kecil. Moncong tumpul jika dilihat dari dorsal dan moncong atas sedikit lebih panjang dari celah mulut jika dilihat dari samping. Tympanum ada tapi tertutup oleh kulit, jari-jari tungkai belakang berselaput penuh hingga ke ujung jari.

\section{Limnonectes leporinus}

Limnonectes leporinus memiliki panjang tubuh (SVL) 29,17-144,00mm. Limnonectes leporinus memiliki tubuh besar berwarna coklat muda hingga coklat tua. Mulut L. leporinus memiliki moncong yang runcing. Bagian dalam anterior rahang bawah terdapat sepasang struktur seperti taring yang jelas dengan ujung yang tumpul. Kelopak mata atas terdapat tonjolan kulit seperti kutil-kutil berukuran kecil.

Kulit pada permukaan dorsal L. leporinus muda memiliki sedikit tonjolan-tonjolan dan akan hilang ketika tubuhnya semakin membesar. Bagian bahu dapat ditemukan corak berbentuk huruf "W" yang samar-samar. Tympanum tampak jelas berbentuk bulat dan sebagian besar berwarna coklat, hanya seperempat dari tympanum yang berwarna hitam. Kulit bagian perut berwarna putih kekuningan hingga putih polos.

Menurut Abdiansyah (2011), L. leporinus memiliki ukuran tubuh berkisar antara $90-125 \mathrm{~mm}$ dengan warna tubuh coklat hingga coklat kemerahan. Menurut Haas et al., (2018) Limnonectes leporinus merupakan katak besar dengan bagian tungkai belakang yang kuat, dan kepala yang lebar berbentik segitiga. Moncong panjang dan meruncing tampak dari atas. Sebagian besar berkulit halus tapi sesekali terdapat tubercle memanjang yang tersebar. Bagian kelopak mata atas terdapat tubercle kecil. Jari tungkai belakang berselaput penuh. Tubuh bagian dorsal berwarna keabu-abuan, coklat pasir hingga colat muda dengan bintik hitam.

\section{Limnonectes paramacrodon}

Limnonectes paramacrodon memiliki panjang tubuh relatif kecil berkisar antara 22,00-33,67mm. Limnonectes paramacrodon bertubuh sedikit lebih ramping. Permukaan kulit dorsal tertutupi kutilkutil kecil dan halus. Kelopak mata bagian atas, terdapat beberapa kutil berukuran lebih besar dari bagian dorsal. Moncong runcing dengan bibir berwarna coklat muda berbelang hitam. Lipatan supra-tympanum memanjang dari bagian posterior mata hingga pangkal tungkai depan. Corak hitam ditemukan di sepanjang posterior mata hingga pangkal tungkai depan berbentuk belah ketupat dan menutupi hampir seluruh tympanum. Bagian ventral tubuh berwarna kekuning-kuningan dan bagian bawah kepala berwarna putih kekuningan dengan bercak abu-abu gelap.

Menurut Kurniati (2008), ciri khas dari jenis $\quad L$. paramacrodon yaitu adanya warna hitam pada tympanum berbentuk segitiga. Betuk tympanum bulat dengan ukuran sekitar setengah dari diameter mata. Jari tungkai depan tidak berselaput sedangkan jari pada tungkai belakang berselaput penuh. Warna dorsal coklat muda hingga coklat tua dengan panjang tubuh mencapai $80 \mathrm{~mm}$.

\section{Family: Rhacophoridae}

\section{Kurixalus appendiculatus}

Kurixalus appendiculatus memiliki panjang tubuh (SVL) berkisar antara 32,86-35,19mm. Kurixalus appendiculatus memiliki ukuran tubuh yang kecil dengan moncong yang pendek dan runcing. Bagian atas kepala terdapat garis berwarna hijau yang menghubungkan kedua mata. Jenis ini memiliki warna tubuh coklat muda hingga coklat tua, pada beberapa individu ada yang berwarna hijau bercampur coklat dan pada begian ventral berwarna putih atau putih kekuningan.

Permukaan tungkai depan dan belakang tertutupi oleh kutil-kutil yang berukuran kecil. Tungkai depan memiliki selaput di antara jari-jarinya. Ujung-ujung jari pada tungkai depan memiliki pelebaran yang jelas berbentuk bulat. Tungkai belakang berukuran kecil. Jari kelima pada tungkai belakang dan jari keempat pada tungkai depan memiliki rumbai-rumbai bergelombang pada sisi terluar jari yang membentang dari ujung jari hingga bagian siku (tungkai depan) dan tumit (tungkai belakang). Bagian ujung tumit terdapat tonjolan kulit yang menyerupai duri. 
Menurut Haas et al., (2018) K. appendiculatus memiliki tubuh yang ramping dan kepala relatif lebar berbentuk segitiga. Ujung moncong merucing tajam. Jari-jari tungkai depan dan belakang memiliki ujung yang melebar membentuk keping. Jari tungkai belakang berselaput hingga tiga sampai empat, jari terluar berselaput di pangkal jari. Segmen terakhir pada tungkai depan dan belakang memiliki pelebaran kulit yang bergelombang di sisi sebelah luar. Dorsal tubuh memiliki tubercle yang tidak beraturan, warna dorsal merupakan kombinasi dari warna coklat, abu-abu dan hijau dengan variasi corak, sedangkan pada bagian kerongkongan dan ventral berwarna krem.

\section{Polypedates colletti}

Polypedates colletti memiliki panjang total tubuh (SVL) berkisar antara 44,38-59,17mm. Polypedates colletti memiliki kepala berbentuk segitiga dengan moncong yang panjang dan runcing. Bagian dorsolateral kepala antara mata dan hidung membentuk sudut yang jelas terlihat, sehingga bagian kepala atas tampak sempit jika dilihat dari atas.

Tubuh bagian dorsal pada Polypedates colletti memiliki corak berbentuk seperti jam pasir pada bagian dorsal berwarna coklat tua. Ventral berwarna putih kekuningan dan bagian bawah kepala hingga dada berwarna putih dengan bercak-bercak keabuan. Tungkai depan kurus dengan jari-jari yang panjang dan kurus. Ujung-ujung jari pada tungkai depan melebar berbentuk sudip dengan ukuran yang besar. Tungkai belakang bagian dorsal berwarna coklat muda dengan garis coklat tua yang melintang dan lebar.

Menurut Abdiansyah (2011), P. colletti memiliki ukuran tubuh berkisar antara $44-77 \mathrm{~mm}$ dengan kepala berbentuk segitiga dan moncong yang runcing. Pada bagian dorsal terdapat pola berbentuk jam pasir.

\section{Polypedates macrotis}

Polypedates macrotis memiliki panjang total tubuh berkisar antara 52,39-78,74mm. Kepala Polypedates macrotis memiliki moncong yang runcing dan panjang. Bagian dorsal dan lateral kepala berwarna coklat muda kekuning-kuningan dan bagian bawah kepala berwarna putih sedikit kekuningan dengan bercak-bercak abu-abu.
Tympanum jelas terlihat berwarna coklat tua. Warna coklat tua pada tympanum memanjang dan menyempit ke arah posterior tubuh hingga pertengahan antara tungkai depan dan belakang. Lateral kepala terdapat garis berwarna coklat yang menghubungkan antara tympanum dan lubang hidung. Bagian dorsal dan lateral tubuh berwarna coklat muda kekuning-kuningan dengan bagian dorsal terdapat corak berwarna hitam berukuran besar. Kulit mulus tanpa tonjolan-tonjolan kulit. Bagian ventral berwarna putih kekuning-kuningan bersih tanpa bercak-bercak dan kloaka berwarna hitam.

Menurut Das et al., (2007) P. macrotis memiliki panjang tubuh hingga $90 \mathrm{~mm}$, dengan ciri-ciri terdapat garis tepal berwarna coklat gelap dari nostril melewati mata dan tympanum hingga bagian tengah sisi tubuh. Menurut Haas et al., (2018) P. macrotis memiliki tubuh ramping dengan tungkai belakang yang panjang, kepala lebar. Kepala dari atas berbentuk segitiga dengan mata yang besar. Ujung jari pada setiap tungkai melebar membentuk kepingan. Selaput renang pada tungkai belakang tidak penuh.

\section{Rhacophorus sp.}

Rhacophorus sp. memiliki panjang total tubuh 30,26 mm. Rhacophorus sp. memiliki kepala dengan moncong yang pendek dan meruncing. Anterior mulut tampak ganjil jika dilihat dari samping, karena moncong bagian atas sedikit lebih maju dan lancip dari moncong bawah. Lipatan kulit pada bagian posterior mata memanjang melalui bagian superior tympanum hingga mendekati pangkal tungkai depan.

Rhaophorus sp. memiliki tubuh yang kecil dan ramping, dengan kulit yang licin dan halus tanpa tonjolan kulit. Kulit pada bagian dorsal berwarna coklat muda yang semakin ke arah ventral semakin berwarna putih. Ventral berwarna putih yang semakin ke arah kloaka semakin kekuningkuningan.

Tungkai belakang memiliki ukuran yang kecil dan panjang. Permukaan kulit dorsal berwarna coklat muda dan bagian ventralnya berwarna kuning. Bagian pangkal femur terluar dekat kloaka terdapat tonjolan kulit yang berukuran kecil berwarna putih susu.

Menurut Inger \& Stuebing (1999) anggota kelompok Rhacophoridae memiliki ukuran tubuh kecil hingga besar dengan selaput pada jari tungkai belakang hingga ujung jari dan sekurang-kurangnya 
setengah jari tungkai depan berselaput. Semua anggota famii Rhacophoridae memiliki ujung jari yang mengembang berbentuk kepingan atau sudip.

\section{Rhacophorus gauni}

Rhacophorus gauni memiliki panjang total tubuh $37,08 \mathrm{~mm}$. Bagian atas kelopak mata merupakan salah satu ciri khas dari $R$. gauni, yaitu adanya beberapa bintil-bintil kecil dan pada bagian bawah mata terdapat garis putih cerah yang menghubungkan antara mata dan bibir atas.

Rhacophorus gauni memiliki tubuh yang kecil dan ramping. Tubuh bagian dorsal dan lateral berwarna coklat muda (habitat asli) atau putih pucat kecoklatan (pada siang hari). Rhacophorus gauni memiliki bercak berwarna coklat kehijauan pada bagian dorsal. Rhacophorus gauni tidak memiliki lipatan kulit pada bagian dorsolateral tubuhnya (lipatan dorsolateral). Permukaan kulit bertabur bintil-bintil yang sangat kecil dan tersebar. Ventral tubuh berwarna coklat muda keputihan, sedangkan bagian bawah kepala berwarna putih. Ujung tumit pada tungkai belakang terdapat tonjolan kulit yang jelas.

Menurut Inger \& Stuebing (1999) R. gauni merupakan katak pohon berukuran kecil dengan panjang tubuh berkisar antara $26-38 \mathrm{~m}$, berbadan ramping dengan moncong yang pendek. Jari kaki tungkai belakang berselaput penuh kecuali jari ke empat. Ujung jari melebar membentuk sudip. Kelopak mata atas terdapat tonjolan kulit berukuran kecil dan juga pada bagian tumit. Dorsal berwarna coklat muda dengan beberapa bintik coklat berukuran besar. Bagian bawah mata terdapat garis putih yang tampak jelas hingga ke bibir atas di bawah mata.

\section{Rhacophorus pardalis}

Rhacophorus pardalis memiliki panjang total tubuh (SVL) 46,65 - 64,42 mm. Rhacophorus pardalis memiliki kepala dengan moncong yang meruncing dan bagian ujung yang rata. Mata berukuran besar dengan garis abu-abu gelap samar-samar yang menghubungkan kedua mata. Rhacophorus pardalis memiliki bentuk tubuh yang ramping, berwarna coklat muda sedikit merah muda pada bagian dorsalnya. Sebagian besar individu yang didapat, terdapat corak " $X$ " pada bagian dorsal dekat tengkuk kepala. Bagian lateral tubuh berwarna kuning cerah dengan corak bulatan hitam yang saling tersambung satu sama lain juga terdapat beberapa bagian yang berwarna oranye. Ventral tubuh berwarna oranye cerah dengan corak kuning cerah keputihan berukuran besar.

Tungkai depan berukuran kecil, pendek dan jari-jari dengan selaput warna oranye kemerahan cerah. Selaput pada jari-jari penuh hingga pangkal bantalan jari. Sisi terluar tungkai depan terdapat pelebaran kulit yang pipih, memanjang dari pangkal antebranchium hingga pangkal pelebaran jari ke empat. Bagian dalam sikut (sudut antara branchium dan antebranchium) terdapat selaput yang mengikat kedua bagian tersebut. Tungkai belakang kurus dan panjang. Jari-jari kurus panjang dan berselaput penuh, berwarna oranye kemerahan terang. Sisi terluar tarsus dan jari ke lima terdapat lipatan kulit yang pipih dan melebar ke arah samping mulai dari pangkal tarsus hingga pangkal pelebaran ujung jari.

Menurut Haas et al., (2018) R. pardalis memiliki tubuh yang mata ramping pada jantan dan gemuk pada betina. Kepala lebar dan pipih dengan besar. Tungkai depan dan belakang besar dengan selaput berwarna merah. Ujung jari pada setiap tungkai melebar. Kulit bagian dorsal tubuh bergranular halus, berwarna coklat dengan bintik hitam atau sedikit bulat gelap yang berpadu dengan bintik putih. Bagian sisi terdapat corak bewarna kuninghitam atau kuning merah yang merupakan karakteristik khas jenis ini.

\section{DAFTAR PUSTAKA}

Abdiansyah, R, 2011, Studi Keanekaragaman Jenis Amfibi Di Kawasan Lindung Sungai Lesan, Kalimantan Timur, Skripsi, Fakultas Kehutanan, Institut Pertanian Bogor, Bogor

Bawono, BT, \& Mashdurohatun, A, 2011, 'Penegakan Hukum Pidana Di Bidang Illegal Logging Bagi Kelestarian Lingkungan Hidup Dan Upaya Penanggulangannya', Jurnal Hukum, 26(2)

Das, I, Jankowski, A, Makmor, MIB, \& Haas, A, 2007, 'Species Diversity, Elevational distribution and Reproductive modes in an Amphibian Community at the Matang Range, Sarawak (Borneo)', Mitteilungen aus dem Hamburgischen Zoologischen Museum und Institut, Band 104, S. 141-174

Haas, A, Boon-hee, K, Joseph, A, Asri, M, Das, I, Hagmann, R, Schwander, L, \& Hertwig, ST, 2018, 'An Update Cheklist of the Amphibian Diversity Of Maliau Basin Conservation Area, Sabah, Malaysia', Evolutionary Systematics, 2 : 89-114 
Heyer, WR, Donnelly, MA, McDiarmid, RW, Hayek, LC, \& Foster, MS, 1994, Standard Techniques for Inventory and Monitoring : Measuring and Monitoring Biological Diversity Standard Methods for Amphibians. Smithsonian Institution Press, Washington and London, 557 hal

Inger, RF, \& Stuebing, RB, 2005, A Field Guide to the: Frogs of Borneo, Second Edition, Natural Histori Publication (Borneo), Sabah, 191 hal

Inger, RF, \& Stuebing, RB, 1999, Panduan Lapangan : Katak-Katak Borneo, Natural Histori Publication (Borneo), Sabah, 191 hal

Inger, FR, Stuart, BL, \& Iskandar, DT, 2009, 'Systematicts of a Widespeard Southeast Asian Frog, Rana chalconota (Amphibian: Anura: Ranidae)', Zoological Journal of the Linnean Society, 155 : 123-147

Iskandar, DT, 1998, Amfibi Jawa Bali, Pusat Penelitian Biologi - LIPI, Jakarta, 117 hal

IUCN, 2008, Red list category, diakses 2 februari 2016, $<$ http ://www.iucnredlist.org/>

Kamsi, M, Handayani, S, Siregar, AJ, \& Fredriksson, G, 2017, Buku Panduan Lapangan Amfibi Reptil Kawasan Hutan Batang Toru, Herpetologer Mania Publishing, Medan.

Knott, CD, 1999, Reproductive, Physiological and Behavioral Responses of Orangutans in Borneo to Fluctuation in Food Availability, Thesis, Harvard University, Cambridge, 366 hal

Kurniati, H, 2008, 'Jenis-jenis Kodok Berukuran Besar Yang dapat Dikonsumsi dan Mampu Beradaptasi dengan Habitat Persawahan di Sumatra', Fauna Indonesia, 8(1): 6-9

Kusrini, MD, 2008, Pedoman Penelitian dan Survei Amfibi di Alam, Pustaka Media Konservasi, Bogor, 154 hal

Malkmus, Manthey, U, Vogel, G, Hoffmann, P, \& Kosuch, J, 2002, Amphibians and Reptiles of Mount Kinabalu (North Borneo), A.R.G. Ganter Verlag K.G., Ruggell, 426 hal

Matsui, M, 2011, 'Taxonomic Revision of One of the Old World's Smallest Frogs, with Description of a New Bornean Microhyla (Amphibia, Microhylidae)', Zootaxa, 2814 : 33-49

Rifanjani, S, 2015, Fragmentasi Hutan dan Pengaruhnya Terhadap Penggunaan Ruang Habitat Orangutan di Taman Nasional Gunung Palung, Disertasi, Universitas Gajah Mada, Yogyakarta
Shimada, T, Matsui, M, Yambun, P, \& Sudin, A, 2011, 'A Taxonomic Study of Whitehead's Torrent Frog, Meristogenys Whiteheadi, with Description of Two New Species (Amphibia: Ranidae)', Zoological Journal of the Linnean Society, 161 : 157-183

Stuart, BL, 2006, 'A Collection of Amphibians and Reptiles From Hilly Eastern Cambodia', The Raffles Bulletin of Zoology, 54 (1) : 129 - 155

Tran Dao, TA, Le, QK, Le, KV, Vu, TN, Nguyen, TQ, Bohme, W, \& Ziegler, T, 2010, 'First and Preliminary Frog Records (Amphibia : Anura) from Quang Ngai Province, Vietnam', Herpetology Notes, 3 : 111-119

Triesita, NIP, Pratama, MYA, Pahlevi, MI, Jamaluddin, MA, \& Hanifa, BF, 2016, Komposisi Amfibi Ordo Anura di Kawasan Wisata Air Terjun Ironggolo Kediri sebagai Bio-Indikator Alami Pencemaran Lingkungan, Prosiding Semnas Hayati IV, Universitas Nusantara PGRI, Kediri

Warguez, DA, Mondejar, EP, \& Demayo, CG, 2013, 'Frogs and their Microhabitat Preference in the Agricultural and Secondary Forest Areas in the Vicinity of Mt. Kalatugan Mountain, Bukidnon, Philippines', International Research Journal of Biological Sciences, 2 (10) : $51-63$ 